\title{
Foreign Currency Translation Method Choice: Insights From Game Theory
}

\author{
Jo Ann M. Pinto, (Email: pintoj@mail.montclair.edu), Montclair State University
}

\begin{abstract}
This paper utilizes a game-theoretical framework to analyze managerial behavior in the context of choosing foreign currency translation methods. The aforementioned problem can be constructed as a model of decision-making under uncertainty. The results of this analysis are as follows: adopt the current rate method when managerial compensation is a function of reported accounting earnings; conversely the temporal method should be employed when managerial compensation takes the form of stock options.
\end{abstract}

\section{Introduction}

his paper utilizes a game-theoretical framework to analyze managerial behavior in the context of choosing foreign currency translation accounting methods. Prior research (see Watts and Zimmerman (1990) for a review of the extant literature) has established that managers, when given a choice between various accounting methods, ${ }^{1}$ will adopt financial reporting practices which maximize their expected compensation; in the literature this phenomena has been labeled the Bonus Theory explanation of accounting method choice. The Bonus Theory falls under the more general rubric of Positive Accounting Theory.

Positive Accounting Theory rests on the assumption that managers will act opportunistically when adopting accounting reporting methods. Prior empirical research has examined such accounting choices as the adoption of LIFO versus FIFO inventory valuation methods (Lee and Hsieh, 1985), the capitalization versus expensing of research and development costs (Daley and Vigeland, 1983), and consolidation policy (Mian and Smith, 1990).

An item of accounting method choice which has received limited attention in the academic literature (to date, only Kirsch and Evans (1994) and Bartov and Bodnar (1996) have addressed this issue) centers around the selection of foreign currency translation method. Translation occurs at the balance sheet date when the foreign domiciled assets and liabilities of U.S. multinationals are converted into dollar equivalents. Currently two such methods exist: the temporal method and the current rate method. In cases where a U.S. firm has substantial overseas operations, adopting one method over the other can produce significantly different net income numbers.

The issue of translation method choice increases in significance as U.S. firms expand their global activities. There is a growing tendency for U.S. corporations to have foreign direct investments. In 1997 the market value of total U.S. overseas investment exceeded \$1.7 trillion (Survey of Current Business, July 1998). In nominal dollars, U.S. direct investment increased over 300 percent between 1982 and 1997. ${ }^{2}$ In addition, Accounting Trends \& Techniques reported that the number of corporations which referenced translation adjustments in their annual reports increased from 27 percent in 1980 to 56 percent in 1995 of the six hundred firms in its annual survey. Finally, Hines (1996) documents that U.S. multinationals pay dividends from foreign earnings at three times the rate relative to domestic earnings and Mataloni (1998) reports that the overseas operations account for approximately 30 percent of the profits of U.S. multinationals.

\footnotetext{
${ }^{1}$ For example, managers have the ability to choose between various inventory, depreciation, and amortization methods. It follows that "bottom line earnings" are jointly a function of actual operating results and accounting method. Accounting methods must be disclosed in the notes to the financial statements and in general cannot be changed from year to year.
}

${ }^{2}$ In real terms, this increase exceeded 150 percent during this fifteen year time period. 
The remainder of this paper is organized as follows. Section II provides an overview of the foreign currency translation issue. Section III delineates the game-theoretic model. Section IV presents the model solution assuming managers receive bonuses contingent on reported profits. Section V presents the model solution assuming managers are compensated with stock options. Section VI concludes with an analysis and suggestions for further research.

\section{Accounting for Foreign Operations}

\subsection{An Overview of Translation}

The overseas assets and liabilities of U.S. multinationals must be converted from the local currency into dollar equivalents at the balance sheet date; this process is known as translation. Under the temporal method (Statement of Financial Accounting Standards No. 8, Accounting for the Translation of Foreign Currency Transactions and Foreign Currency Financial Statements), essentially all current assets and liabilities are translated at the exchange rate in effect at the balance sheet date ${ }^{3}$ long term assets and liabilities are translated at the historical exchange rate; i.e., the rate in effect when the asset was purchased or the liability incurred. The translation adjustment is therefore the year-over-year change in dollar terms of the net current assets. ${ }^{4}$ Under the temporal method translation adjustments are recognized in net income.

Under the current rate method (Statement of Financial Accounting Standards No.52, Foreign Currency Translation), all assets and liabilities are converted from the local currency into dollars at the balance sheet date. The translation adjustment is therefore the annual change in dollar equivalents of the total net assets of the foreign subsidiary. Under the current rate method translation gains (losses) do not flow through net income but are instead reported directly as an addition to (subtraction from) stockholders' equity.

The current rate method was introduced in 1981 as an alternative to the temporal method of translation; the temporal method was widely criticized by corporate managers who contended its application increased volatility in reported earnings. ${ }^{5}$ When managers' bonuses are tied to reported accounting earnings the temporal method increases the riskiness of annual managerial compensation. When the current rate method is employed, translation adjustments bypass the income statement altogether and instead are reported as a separate component of stockholders' equity. ${ }^{6} \quad$ Recent evidence (Bartov, 1997) suggests, however, that equity markets are not fooled by this translucent method of accounting, i.e., the efficient market hypotheses holds in that investors add translation adjustments to reported net income in order to derive a "comprehensive" measure of firm income. In addition, this relationship is not symmetric in that translation losses are immediately impounded into stock prices whereas translation gains are not.

Adoption of the current rate method can therefore be problematic for managers who receive part of their compensation in the form of stock options. Negative stock price reactions to non-earnings accounting information may greatly reduce the value of the options granted. Furthermore, given that under the current rate method the translation adjustment is a function of all foreign net assets, not just current net assets, a large change in the value of a foreign currency relative to the dollar can produce significant translation adjustments.

\footnotetext{
${ }^{3}$ Specifically, under the temporal method inventories and marketable securities can be translated at either the historical or current exchange rate contingent on the accounting method used to value the asset in the local currency. Inventory carried at cost is translated at the historical exchange rate. Inventory carried under alternative methods, such as replacement cost, current selling cost or net realizable value, is translated at the current (balance sheet date) exchange rate. Marketable securities carried at cost are accounted for using historical exchange rates while those valued at the current market price are translated at the current exchange rate. (SFAS No. 8, paragraphs 11-13).

${ }^{4}$ Net current assets are current assets less current liabilities.

${ }^{5}$ The Financial Executives Institute led the fight to have translation adjustments removed from net income.

${ }^{6}$ Bernstein (1993) laments, “ In allowing gains and losses to bypass the income statement, it [the current rate method] reintroduced, in somewhat modified form, the long-discredited "charge to surplus" approach. That, in effect, removed from current operations the risk of operating in a foreign environment along with the risks of changes in exchange rates." (p. 302)
} 


\subsection{Accounting Method Choice}

Current accounting standards allow managers to select either the temporal method or the current rate method. This choice is a function of the functional currency selected to account for the operations of the foreign subsidiary. Firms can elect the local currency, the dollar or the currency of a third country as the functional currency of their foreign subsidiaries. ${ }^{7}$ Firms who select the dollar as the functional currency use the temporal method of translation whereas those firms selecting the local currency as the functional currency are required to employ the current rate method of translation. In addition, firms that operate subsidiaries in hyper-inflationary ${ }^{8}$ environments are compelled to adopt the dollar as the functional currency. The FASB's primary motivation in allowing a choice amongst functional currencies is to enable firms to select that currency which best reflects the economic environment in which their foreign affiliates operate.

Specifically, SFAS No. 52 has identified six factors that are to be considered both individually and collectively when selecting the functional currency of a foreign affiliate. These six factors include: cash flow indicators, sales price indicators, sales market indicators, expense indicators, financing indicators, and intercompany transactions and arrangements indicators. In addition, SFAS No. 52 does not suggest that a particular weight should be assigned to any one of the six factors. An example of a situation in which financing indicators would point to the selection of the dollar as the functional currency would be where a foreign affiliate carries dollar-denominated debt on its balance sheet. Complications arise, however, when several of the indicators point to the dollar as the functional currency while other indicators point to the local currency. In these cases the FASB allows management latitude in selecting the functional currency. This leeway is explicitly stated in SFAS No. 52:

Management is in the best position to obtain the pertinent facts and weigh their relative importance in determining the functional currency for each operation. It is important to recognize that management's judgment is essential and paramount in this determination, provided only that it is not contradicted by the facts. (SFAS No. 52, paragraph 41).

\subsection{Evidence of Managerial Opportunism}

After SFAS No. 52 became effective in 1983 several researchers conducted surveys of leading corporations to gain insight into how they went about selecting a functional currency. The first of these studies, Arnold and Holder (1986) was sponsored and published by the Financial Executives Research Foundation. Arnold and Holder surveyed 174 Fortune 500 companies and later directly interviewed financial executives from 22 of these firms. Verbal responses solicited during their investigation point to the fact that corporate managers exercised substantial discretion when selecting the functional currency for their foreign affiliates. In addition Arnold and Holder arrived at the conclusion that, "the approaches [for selecting a functional currency] used by these companies did not involve the creation and evaluation of a structured analytical or scoring mechanism." (p. 88) Several of the comments recorded by the researchers underscore the lack of objectivity involved in this decision process:

"There has been a lot of debate; the chairman of our board finally made the decision and stated, 'That's the last I want to hear of that." ",

"We went at it from the perspective of trying to use the U.S. dollar wherever I could within the guidelines of SFAS No. 52. Culturally, I believe that is the right way to run a U.S. multinational company. [And] I think management can make any situation it wants come out the way it wants."

\footnotetext{
${ }^{7}$ In practice, firms rarely utilize the currency of a third country as the functional currency; therefore the scope of this paper only considers the first two cases.

${ }^{8} \mathrm{~A}$ hyper-inflationary environment exists when a country has a three year cumulative inflation rate in excess of 100\% (SFAS No. 52, paragraph $11)$.
} 
"Within our company I emphasize the balance sheet; however, shareholders and analysts focus on profit and loss." Therefore, removing the effects of translation from earnings was attractive to that individual."

Further evidence of managerial opportunism is manifested by the fact that companies apparently select either the dollar or the local currency as the functional currency for all their foreign affiliates. This fact suggests they are "managing" their financial statement numbers rather than rigorously applying SFAS No. 52 guidelines on a foreign entity-by-entity basis.

Additional evidence of the ability to exercise management discretion was uncovered by the author of this study. I identified over 100 pairs of companies, matched by 4-digit SIC code, where one company utilized the local currency while its counterpart used the dollar as its functional currency for foreign operations. Ex ante, I would expect firms in the same industry to have foreign operations with similar cash flow implications for the parent company and therefore apply the FASB criteria in a manner that would lead to similar if not identical outcomes. Table 1 below provides a sampling of the evidence that I have compiled.

Table 1:

Functional Currency Choice By Industrial Grouping, Selected Firms, 1996

\begin{tabular}{|c|c|l|l|}
\hline $\begin{array}{c}\text { Pair } \\
\text { Number }\end{array}$ & $\begin{array}{c}\text { Primary } \\
\text { Sic Code }\end{array}$ & \multicolumn{1}{|c|}{$\begin{array}{c}\text { Company } \\
\text { Names }\end{array}$} & \multicolumn{1}{c|}{$\begin{array}{c}\text { Functional } \\
\text { Currency }\end{array}$} \\
\hline 1 & 1040 & $\begin{array}{l}\text { Homestake Mining } \\
\text { Barrick Gold Corp. }\end{array}$ & $\begin{array}{l}\text { Local Currency } \\
\text { Dollar }\end{array}$ \\
\hline 2 & 2834 & $\begin{array}{l}\text { American Home Products } \\
\text { Merck \& Company }\end{array}$ & $\begin{array}{l}\text { Local Currency } \\
\text { Dollar }\end{array}$ \\
\hline 3 & 3312 & $\begin{array}{l}\text { Oregon Steel } \\
\text { Bethlehem Steel }\end{array}$ & $\begin{array}{l}\text { Local Currency } \\
\text { Dollar }\end{array}$ \\
\hline 4 & 3570 & $\begin{array}{l}\text { IBM } \\
\text { Hewlett Packard }\end{array}$ & $\begin{array}{l}\text { Local Currency } \\
\text { Dollar }\end{array}$ \\
\hline 5 & 3576 & $\begin{array}{l}\text { Bay Networks } \\
\text { Cirrus Logic, Inc. }\end{array}$ & $\begin{array}{l}\text { Local Currency } \\
\text { Dollar }\end{array}$ \\
\hline 6 & 3715 & $\begin{array}{l}\text { Railamerica } \\
\text { Wabash National Corp. }\end{array}$ & $\begin{array}{l}\text { Local Currency } \\
\text { Dollar }\end{array}$ \\
\hline 7 & 3861 & $\begin{array}{l}\text { Polaroid Corp. } \\
\text { IMAX Corp }\end{array}$ & $\begin{array}{l}\text { Local Currency } \\
\text { Dollar }\end{array}$ \\
\hline 8 & 4911 & $\begin{array}{l}\text { American Electric Power } \\
\text { GPU, Inc. }\end{array}$ & $\begin{array}{l}\text { Local Currency } \\
\text { Dollar }\end{array}$ \\
\hline 9 & 7372 & $\begin{array}{l}\text { Geoworks Corp. } \\
\text { Systemsoft Corp. }\end{array}$ & $\begin{array}{l}\text { Local Currency } \\
\text { Dollar }\end{array}$ \\
\hline 10 & 8700 & $\begin{array}{l}\text { Opinion Research Corp. } \\
\text { Audits and Surveys Worldwide }\end{array}$ & $\begin{array}{l}\text { Local Currency } \\
\text { Dollar }\end{array}$ \\
\hline
\end{tabular}




\subsection{Lack of Clarity in the FASB Classification Scheme}

Given the evidence, the FASB's classification scheme unfortunately raises more questions than it answers. Firstly, firms can and do have ample leeway in deciding under which category they fit. In fact a wide body of literature suggests that this classification scheme is so porous that management simply decides which way it wants to translate foreign operations and then ex post facto uses some portion of the FASB's rules to justify their decision. A related Forbes (1986) article cynically poses the question:"What do open marriages and the accounting rules for changes in foreign exchange have in common?" Answer: "Plenty of Opportunity to Fool Around."

During the late 1990's, approximately 75-80 percent of all U.S. multinationals utilized the local currency as the functional currency while the remaining $20-25$ percent used the dollar as the functional currency. ${ }^{910}$ In addition, these percentages appear to be relatively stable over time. ${ }^{11}$

Given that managers can and seemingly do have the ability to use the FASB's rules to their advantage, how do they choose between the current rate and temporal rate method of translation? Given the choice, Bartov and Bodnar (1996) contend that managers will select the current rate method, i.e., use the local currency as the functional currency. They posit that managers prefer the current rate method because its application reduces information asymmetries; a reduction in information asymmetries results in lower transaction costs and increases the liquidity of firm shares in equity markets. Bartov and Bodnar's results rest on the assumption that information asymmetries are reduced at the point in time when firms switch from the temporal to the current rate method of translation. However, their analysis leaves unanswered a fundamental question: if the current rate method is truly an asymmetry-reducing accounting method, why do fully one-quarter of all U.S. multinationals continue to report under the rules of the temporal method?

As a competing hypothesis, this paper argues that managers select accounting methods to maximize their expected compensation. The following section uses game theoretical concepts to construct a framework for the analysis of managerial decision making in the context of accounting method choice.

\section{Model Description}

The aforementioned problem can be constructed as a model of decision-making under uncertainty. Utilizing a game-theoretic framework, I construct a two-person game where the column player is "nature" and the row player is the self-interested or opportunistic manger. For the purposes of this illustration the state of nature is unknown to the manager at the point in time when he makes his decision; i.e., nature moves after the manager. The state of nature refers to the direction and magnitude of the movement of the foreign currency against the U.S. dollar. Four possible states are possible: a "large" appreciation, a "large" depreciation, a "small" appreciation, and a "small" depreciation. The manager also does not know the probability of the occurrence of each state of nature.

The manager must simultaneously decide upon two factors: where to locate the foreign direct investment and which accounting methodology to adopt. The manager can invest in either a low-growth (developed) country or high-growth (developing) country. The developing country investment will produce a higher level of profits; however, large currency devaluations can negate the benefits of increased profitability. The manager also has to decide which translation method to adopt in order to convert the foreign domiciled assets and liabilities into U.S. dollars. The trade-off between the two methods is as follows: the temporal method generates smaller translation adjustments

\footnotetext{
${ }^{9}$ Hyper-inflationary pressures can no longer explain this differential. As of the early 1990's most countries in the world where U.S. firms have sizable amounts of foreign direct investment, especially those in Latin America, have eradicated hyperinflation.

${ }^{10}$ These percentages were calculated by the author of this study in by examining the footnote disclosures of 668 U.S. multinationals for fiscal year 1996.

${ }^{11}$ Bartov and Bodnar (1996) indicate that 80 percent of the 788 firms in their study employed the current rate method; the remaining 20 percent utilized the temporal method. Their sample was drawn from early 1980's data.
} 
but unlike the current rate method these adjustments flow through net income. Once the manger makes these decisions, they cannot be reversed. ${ }^{12}$

The basic premise of this game is that the manager's decision making is influenced by an additional factor: the form of his compensation. In Payoff Matrix I below, the manager receives a bonus based upon reported accounting profits. In Payoff Matrix II, the manager receives stock options whose value fluctuates with the market value of the firm's equity.

The methodology for solving this problem is delineated in Luce and Raiffa (1957) and Binmore (1992). The solution of the problem involves the search for saddle points ${ }^{13}$ in each of the two 4 x 4 payoff matrices.

\section{Bonus Scheme Contingent Upon Reported Profits}

\section{Payoff Matrix 1}

\begin{tabular}{|c|c|c|c|c|c|}
\hline ActionlState & S1 & S2 & S3 & S4 & Row Minimum \\
\hline A1 & $-{ }^{14}$ & $\$ 110,000$ & $\$ 110,000$ & $\$ 110,000$ & $\$ 110,000$ \\
\hline A2 & - & $\$ 35,000$ & $\$ 125,000$ & $\$ 95,000$ & $\$ 35,000$ \\
\hline A3 & $\$ 50,000$ & $\$ 50,000$ & $\$ 50,000$ & $\$ 50,000$ & $\$ 50,000$ \\
\hline A4 & $\$ 125,000$ & 0 & $\$ 65,000$ & $\$ 35,000$ & 0 \\
\hline $\begin{array}{c}\text { COLUMN } \\
\text { MAXIMUM }\end{array}$ & $\$ 125,000$ & $\$ 110,000$ & $\$ 125,000$ & $\$ 110,000$ & \\
\hline
\end{tabular}

WHERE: $\quad$ S1 $=$ State of Nature when a "large" appreciation (defined as an annual change of 25\% against the dollar) occurs;

$\mathrm{S} 2=$ State of Nature when a "large" depreciation (defined as an annual change of $25 \%$ against the dollar) occurs;

S3= State of Nature when a "small" appreciation (defined as an annual change of 5\% against the dollar) occurs:

$\mathrm{S} 4=$ State of Nature when a "small" depreciation (defined as an annual change of 5\% against the dollar) occurs;

$\mathrm{A} 1=$ Action taken where manager invests in a high-growth (developing) country and use the current rate method of accounting (i.e., translation adjustments do not flow through net income);

A2=Action taken where manager invests in a high-growth (developing) country and use the temporal method of accounting (i.e., translation adjustments flow through net income);

A3 = Action taken where manager invests in a low-growth (developed) country and use the current rate method of accounting (i.e., translation adjustments do not flow through net income);

\footnotetext{
${ }^{12}$ More preciously, they cannot be reversed costlessly. Specifically, SFAS No. 52, paragraph 9 states, "Once the functional currency for a foreign entity is determined, that determination shall be used consistently unless significant changes in economic facts and circumstances indicate clearly that the functional currency has changed." The implication of this standard for game theory is that randomized strategies cannot be used; hence, only pure strategies are allowed.

${ }^{13}$ Saddle points are the points that are simultaneously the maximum of one function and the minimum of another.

${ }^{14}$ Cells A1/S1 and A2/S1are left empty due to the fact that a large appreciation of a developing country currency against the U.S. dollar is an event that is highly unlikely to occur. The payoff amount for these cells is undefined.
} 
A4= Action taken where manager invests in a low-growth (developed) country and use the temporal method of accounting (i.e., translation adjustments flow through net income).

Details of the accounting earnings bonus scheme are as follows:

1. The manger receives a $\$ 10,000$ bonus if profits reach a level of $\$ 500,000$ and zero if profits fall below this level. In addition, he receives an additional bonus of 10 percent of total profits that exceed the $\$ 500,000$ threshold.

2. If the manger invests in a high-growth (developing country), reported profits, exclusive of translation adjustments, total $\$ 1,500,000$. Conversely, if the manager invests in a low growth (developed) country, reported profits, exclusive of translation adjustments, total $\$ 900,000$.

3. Translation adjustments are calculated as the change in dollar value of net current assets when the dollar is used as the reporting currency. For the purposes of this illustration, it is assumed the corporation controls $\$ 3,000,000$ in foreign domiciled net current assets.

4. All calculations ignore the impact of income tax considerations.

\section{Bonus Scheme As A Function of Equity Prices}

Payoff Matrix 2

\begin{tabular}{|c|c|c|c|c|c|}
\hline ActionlState & S1 & S2 & S3 & S4 & Row Minimum \\
\hline A1 & - & $-\$ 350,000$ & $\$ 150,000$ & 0 & $-\$ 350,000$ \\
\hline A2 & - & 0 & $\$ 180,000$ & $\$ 120,000$ & 0 \\
\hline A3 & $\$ 30,000$ & $-\$ 470,000$ & $\$ 30,000$ & $-\$ 70,000$ & $-\$ 470,000$ \\
\hline A4 & $\$ 180,000$ & $-\$ 120,000$ & $\$ 60,000$ & 0 & $-\$ 120,000$ \\
\hline $\begin{array}{c}\text { COLUMN } \\
\text { MAXIMUM }\end{array}$ & $\$ 180,000$ & 0 & $\$ 180,000$ & $\$ 120,000$ & \\
\hline
\end{tabular}

N.B.: The descriptions for the States and Actions are identical to those in the previous section.

Details of the stock option bonus scheme are as follows:

1. I assume the manager receives 10,000 stock options. The day the options are granted, but before the annual accounting information is released, the market value of the stock equals $\$ 60$. The options allow the manager to purchase the stock for $\$ 55$ per share. This assumption is consistent with evidence presented in Kaplan and Atkinson (1998) which reports that most corporations issue stock options to executives that are "in the money."

2. Upon the release of the annual accounting information, the stock price changes based upon the amount earnings deviate from expected earnings. For the purposes of this illustration, I assume the market is anticipating earnings per share (EPS) to equal \$1.00. The company has 1,000,000 shares outstanding. For every $\$ .10$ actual earnings deviate from expected earnings the stock prices changes by $+/-\$ 2.00$.

3. I assume the market reacts to economic earnings not accounting earnings. Translation adjustments which appear in stockholders' equity but which do not flow through net income constitute a component of economic income. 
4. Translation adjustments, when the local currency is used as the reporting currency, are calculated as a function of total net assets. In contrast, when the dollar is used as the reporting currency, translation adjustments are calculated as a function of net current assets. For the purposes of this illustration, the corporation controls $\$ 10,000,000$ in foreign domiciled net total assets and $\$ 3,000,000$ in foreign net current assets.

5. Translation adjustments that appear in stockholders' equity have an asymmetric function on equity valuation. When they are losses they are considered to be a component of economic income and are immediately impounded into equity prices. Conversely, when they are gains they are disregarded by the market.

6. Translation adjustments that are reported as a component of net income do not have an asymmetric function on equity valuation. Income statement translation adjustments are "buried" in "Other Expenses" and the market cannot discern their impact on bottom line earnings. In this case, reported (accounting) earnings are used by the market to form equity prices.

7. In reality, the value of stock options cannot fall below zero. However, for the purposes of this illustration I show negative values. The logic for this is as follows. At some later date (before the options expires), another even may occur which increases the market value of equity. A share that started at a price of $\$ 53$ is closer to having economic value to the option holder relative to a share priced at $\$ 20$.

\section{Analysis and Discussion}

In order to locate the optimal action in Payoff Matrix I, I first find the minimum payoff amount in each row. Next, I locate the maximum payoff in each column. The minimax value of Payoff Matrix I is $\$ 110,000$ which appears in both cells A1/S2 and A1/S4. The maximin value of Payoff Matrix is $\$ 110,000$, which appears in cells $\mathrm{A} 1 / \mathrm{S} 2, \mathrm{~A} 1 / \mathrm{S} 3$ and A1/S4. It therefore follows that Payoff Matrix I has two saddle points: at A1/S2 and A1/S4. In both strategies cases the manager would therefore select A1, invest in a high-growth (developing) country and adopt the current rate method of translation.

In order to locate the optimal action in Payoff Matrix II, I repeat the procedure outlined for Payoff Matrix I above. The minimax value of Payoff Matrix II is 0 , which corresponds to cell A2/S2. The maximin value of Payoff Matrix I is 0 which corresponds to A2/S2. Payoff Matrix II therefore has a unique saddle point: A2/S2. The manager should therefore select A2, invest in a high-growth (developing) country and adopt the temporal method of translation.

In Payoff Matrix I, under Action/State A1 and A3 managerial bonuses do not vary at all; i.e., accounting earnings are not subjected to variation (risk) under either case when the current rate method of translation is utilized. However, large swings in accounting earnings and therefore managerial bonuses occur under Action/State A2 and A4 when the temporal method is employed.

The converse occurs in Payoff Matrix II. Under Action/State A1 and A3, large stock price reactions to translation adjustments reported under the current rate method increase the riskiness of the options granted. Furthermore, under Action/State A2 and A4, where the temporal method is utilized, the stock price reaction to translation adjustments is lessened. This latter result corroborates evidence reported by Bartov and Bodnar (1995) which states that, "For SFAS No. 52, there is a significantly positive relation between stock price changes and the foreign currency adjustments for firms which designate a foreign currency as functional currency [current rate method], but no relation for firms choosing the dollar [temporal method] as functional currency." (cited in Bartov and Bodnar (1996) p.402).

Under both compensation schemes, the manger should invest in the high growth country. The decision to invest in the developing country is therefore the dominant strategy under both compensation schemes. However, when compensation is tied to reported accounting profits, the manager has the incentive to utilize an accounting method where translation adjustments bypass the income statement. Conversely, when the manager's compensation is a function of equity prices, the manager would opt to report translation adjustments in net income (the temporal me- 
thod) for two reasons. Firstly, it will be recalled that under the temporal method translation adjustments are a function of net current assets, i.e., a subset of net total assets. Secondly, in an efficient market, all publicly available information is impounded into equity prices irrespective of its location in the financial statements.

\section{Suggestions for Future Research}

The results of the above analysis can be empirically tested in a model of foreign currency translation method choice. A logistic regression model can be constructed where the binary dependent variable is accounting method choice (temporal or current rate). Independent variables would include the form of managerial compensation (i.e., bonuses tied to accounting profits or stock options), and other variables such as location of foreign investment, firm size, extent of internationalization and type of industry.

The above analysis rests on the assumption that managers receive a bonus purely in the form or either stock options or as a function of accounting earnings; this simplifying assumption was necessary in order to keep the model tractable. In reality, as delineated in Kaplan and Atkins (1998), managers typically receive a portion of their bonus based upon accounting earnings in addition to stock options. The empirical analysis would necessarily include a weighting factor on the various components of managerial compensation.

Finally, the issuance of SFAS No. 130, Reporting Comprehensive Income, adds an additional dimension to this analysis. After 1997 managers must select not only the translation method but can now report foreign currency translation adjustments and other components of comprehensive income in one of three formats: (1) on the face of the income statement; (2) in a separate "statement of comprehensive income" or (3) in a "statement of stockholders" equity".

Readers with comments or questions are encouraged to contact the author via email.

\section{References}

1. American Institute of Certified Public Accountants, Accounting Trends and Techniques, AICPA, New York, NY, 1996.

2. Arnold, Jerry L. and William W. Holder, Impact of Statement 52 on Decisions, Financial Reports and Attitudes, Financial Executives Research Foundation, Morristown, NJ, 1986.

3. Bargas, Silvia, "Direct Investment Positions for 1997," Survey of Current Business, July, pp. 35-57, 1998.

4. Bartov, Eli and Gordon M. Bodnar, "Foreign Currency Translation Reporting and the Exchange-Rate Exposure Effect", Journal of International Financial Management and Accounting, Vol. 6, No. 2, pp. 93-114, 1995.

5. Bartov, Eli and Gordon M. Bodnar, "Alternative Accounting Methods, Information Asymmetry and Liquidity: Theory and Evidence", The Accounting Review, Vol. 71, No. 3, pp. 397-418, 1996.

6. Bartov, Eli, "Foreign Currency Exposure of Multinational Firms: Accounting Measures and Market Valuation", Contemporary Accounting Research, Vol. 14, No. 4, Winter, pp. 623-652, 1997.

7. Bernstein, Leopold A., Financial Statement Analysis: Theory, Application, and Interpretation, Irwin, Boston, MA, 1993.

8. Binmore, Ken, Fun and Games: A Text on Game Theory, D.C. Heath and Company, Lexington, MA, 1992.

9. Daley, Lane A. and Robert Vigeland, "The Effect of Debt Covenants and Political Costs on the Choice of Accounting Methods: The Case for R\&D Costs", Journal of Accounting and Economics, 5, pp. 195-211, 1983.

10. Financial Accounting Standards Board, SFAS No. 8, Accounting for the Translation of Foreign Currency Transactions and Foreign Currency Financial Statements, FASB, Stamford, CT, 1975.

11. Financial Accounting Standards Board, SFAS No. 52, Foreign Currency Translation, FASB, Stamford, CT, 1981.

12. Financial Accounting Standards Board, SFAS No. 130, Reporting Comprehensive Income, FASB, Norwalk, CT, 1997.

13. Heins, John, "Plenty of Opportunity to Fool Around", Forbes, June 2, pp. 139-140, 1986. 
14. Hines, J., "Dividends and Profits: Some Unsubtle Foreign Influences", Journal of Finance, Vol. 51, pp. 661-689, 1996.

15. Kaplan, Robert S. and Anthony A. Atkinson, Advanced Management Accounting, Prentice Hall, Upper Saddle River, NJ, 1998.

16. Kirsch, Robert J. and Thomas G. Evans, "The Implementation of SFAS 52: Did the Functional Currency Approach Prevail?", The International Journal of Accounting, Vol. 29, pp. 20-33, 1994.

17. Lee, Chi-In Jevons and David A. Hsieh, "Choice of Inventory Accounting Methods: Comparative Analysis of Alternative Hypotheses", Journal of Accounting Research, Vol. 23, No. 2, Autumn, 1985.

18. Luce, R. Duncan and Howard Raiffa, Games and Decisions: Introduction and Critical Survey, Dover Publications, Inc., New York, NY, 1957.

19. Mataloni, Raymond, Jr., "U.S. Multinational Corporations: Operations in 1996", Survey of Current Business, October, 1998.

20. Mian, Shehzad L. and Clifford W. Smith, Jr., “Incentives for Unconsolidated Financial Reporting”, Journal of Accounting and Economics, Vol. 12, pp. 141-171, 1990.

21. Watts, Ross L. and Jerold L. Zimmerman, "Positive Accounting Theory: A Ten Year Perspective", The Accounting Review, Vol. 65, No. 1, pp. 131-156, 1990. 